\title{
Pressor and renal regional hemodynamic effects of urotensin II in neonatal pigs
}

\author{
Hitesh Soni and Adebowale Adebiyi \\ Department of Physiology, University of Tennessee Health Science Center, Memphis, Tennessee 38163, USA
}

Correspondence should be addressed to A Adebiyi

Email aadebiyi@uthsc.edu

\begin{abstract}
Renal expression of the peptide hormone urotensin II (UII) and its receptor (UTR) are dependent on kidney maturation and anatomical regions. However, renal regional hemodynamic effects of UII in neonates are unclear. Here, we investigated regional hemodynamic responses to acute intrarenal arterial administration of UII in newborn pigs. Western immunoblotting and immunofluorescence confirmed UTR expression and membrane localization in newborn pig renal afferent arterioles and afferent arteriolar smooth muscle cells respectively. Intrarenal arterial bolus injections of human UII (hUII; $1-100 \mathrm{ng} / \mathrm{kg}$ ) resulted in a dose-dependent decrease in total renal blood flow (RBF) and an increase in mean arterial pressure (MAP) and renal vascular resistance (RVR) in newborn pigs. Moreover, hUll dose dependently reduced cortical blood flow (CBF) but increased medullary blood flow (MBF) in the piglets. hUll-induced MAP elevation and hemodynamic changes were inhibited by urantide, a UTR antagonist, but not losartan, a type 1 angiotensin II receptor antagonist. U-73122, a phospholipase C (PLC) inhibitor, and 2-aminoethoxydiphenyl borate, an inositol 1,4,5 trisphosphate $\left(\mathrm{IP}_{3}\right)$ receptor antagonist, attenuated hUll-induced MAP and RVR elevations, RBF and CBF reductions, but not MBF increase. These findings indicate that intrarenal arterial administration of hUll elevates blood pressure and induces region-selective renal hemodynamic changes in newborn pigs. Our data also suggest that the $\mathrm{PLC} / \mathrm{PP}_{3}$ signaling pathway contributes to hUll-induced alterations in MAP, RBF, RVR, and CBF but not MBF in newborn pigs.
\end{abstract}
Key Words
- Urotensin II
- neonates
- renal hemodynamics
- mean arterial pressure
- renal arterioles

Journal of Endocrinology (2013) 217, 317-326

\section{Introduction}

The kidney is a major source of vasoactive mediators, including angiotensin II (AngII), prostaglandins (PGs), endothelin-1 (ET-1), bradykinin, thromboxane, and urotensin II (UII). These compounds can act in an endocrine, autocrine, or paracrine fashion to modulate cardiovascular and renal homeostasis. Thus, alterations in expression, function, and regulation of these mediators and their receptors underlie pathophysiological mechanisms of a variety of cardiovascular and renal diseases (Douglas et al. 2004, Ponnuchamy \& Khalil 2009).

UII, a cyclic peptide hormone, has been described as the most potent vasoconstrictor, constricting human coronary, mammary and radial arteries, rat aorta and pulmonary arteries, pig and monkey coronary arteries, and monkey basilar, renal, and mesenteric arteries with potency up to 109-fold more than ET-1 (Ames et al. 1999,

Published by Bioscientifica Ltd. 
Douglas et al. 2000, MacLean et al. 2000, Maguire et al. 2000). However, other studies have shown that UII can also cause vasodilation. For example, UII-induced endothelium-dependent vasodilation in rat-isolated coronary and mesenteric arteries precontracted with 5-HT and methoxamine respectively (Bottrill et al. 2000). UII also dilated ET-1-precontracted human pulmonary and abdominal resistance-sized arteries and phenylephrineprecontracted rat renal arteries (Stirrat et al. 2001, Zhang et al. 2003). These studies suggest that UII-induced regulation of vascular tone may depend on species and blood vessel anatomical origin or size (Douglas et al. 2000, Ashton 2006, Zoccali \& Mallamaci 2008).

Alterations in UII and UII receptor (UTR) expression and plasma and urinary UII concentrations have been associated with renal dysfunctions, including hypertensive renal disease, diabetic nephropathy, glomerulonephritis, and renal tubular diseases (Matsushita et al. 2001, Douglas et al. 2004, Langham et al. 2004, Ashton 2006, Balat et al. 2007, Ross et al. 2010). However, the physiological role of UII in the kidney remains controversial with studies reporting attenuation and elevation of important renal parameters, including total renal blood flow (RBF), glomerular filtration rate (GFR), urine flow rate $(\mathrm{UV})$, and urinary sodium $\left(\mathrm{U}_{\mathrm{Na}} \mathrm{V}\right)$ and potassium $\left(\mathrm{U}_{\mathrm{K}} \mathrm{V}\right)$ excretion (Zhang et al. 2003, Ovcharenko et al. 2006, Song et al. 2006, Abdel-Razik et al. 2008a,b, Shi et al. 2008).

A recent study demonstrated that UII plasma level was increased after birth in lambs (Simpson et al. 2010). An examination of the ontogenetic pattern of UII and UTR expression in rat kidney has also revealed regional variability in UII and UTR expression from embryonic day 19 to 4 weeks after birth (Forty \& Ashton 2012). However, unlike in adult, rat UII (rUII) did not alter renal hemodynamics in young (4-week-old) rats (Forty \& Ashton 2012).

The physiological characteristics of newborn renal circulation differ significantly from those of young and old adults (Hook \& Bailie 1979, Toth-Heyn et al. 2000). Newborns are unable to concentrate urine and exhibit higher renal vascular resistance (RVR) and lower RBF and GFR compared with adults (Hook \& Bailie 1979, Toth-Heyn et al. 2000). Accumulating evidence also suggests that alterations in the physiological functions of endogenous vasoactive mediators contribute to maturation-dependent changes in renal hemodynamics (Hook \& Bailie 1979, Toth-Heyn et al. 2000). Here, we examined two important, yet largely unexplored, renal actions of UII. First, we studied the effects of UII on neonatal renal circulation. Second, we tested the hypothesis that UII differentially regulate neonatal regional renal perfusion.

\section{Materials and methods}

\section{Animals}

All animal protocols were reviewed and approved by the Animal Care and Use Committee of the University of Tennessee Health Science Center (UTHSC). Newborn pigs (1-3 day old; $1.5-2 \mathrm{~kg}$ ) were purchased from Nichols Hog Farm (Olive Branch, MS, USA) and maintained at the UTHSC Comparative Medicine Department animal core facility. Animals were used within the first week of life.

\section{Renal vascular smooth muscle cell isolation}

Afferent arterioles were manually dissected from decapsulated newborn pig kidneys using a Zeiss SteREO Discovery.V12 stereomicroscope (Carl Zeiss, Thornwood, NY, USA). Smooth muscle cells were dissociated from the microvessels using a HEPES-buffered isolation solution containing (in $\mathrm{mM}$ ) $55 \mathrm{NaCl}, 80$ sodium glutamate, $5.6 \mathrm{KCl}, 2 \mathrm{MgCl}_{2}, 10$ HEPES, and 10 glucose ( $\mathrm{pH}$ 7.3). Afferent arterioles were placed into isolation solution containing $1 \mathrm{mg} / \mathrm{ml}$ papain, $500 \mu \mathrm{g} / \mathrm{ml}$ elastase, $1 \mathrm{mg} / \mathrm{ml}$ dithioerythritol, and $1 \mathrm{mg} / \mathrm{ml}$ BSA for $\sim 45 \mathrm{~min}$ at $37^{\circ} \mathrm{C}$. Arterioles were then washed and incubated in isolation solution containing $1 \mathrm{mg} / \mathrm{ml}$ collagenase $\mathrm{F}$ and $\mathrm{H}(2: 1), 100 \mu \mathrm{M} \mathrm{CaCl}_{2}$ and $1 \mathrm{mg} / \mathrm{ml} \mathrm{BSA}$ for $\sim 20 \mathrm{~min}$ at $37^{\circ} \mathrm{C}$. Digested vessels were subsequently washed in isolation solution and triturated using a fire-polished glass Pasteur pipette to yield single smooth muscle cells.

\section{Immunofluorescence}

Renal vascular smooth muscle cells were allowed to adhere to collagen-coated coverslips. The cells were then fixed with $4 \%$ paraformaldehyde in PBS for $\sim 15 \mathrm{~min}$ and permeabilized with $0.2 \%$ Triton X-100 for $\sim 20 \mathrm{~min}$ at room temperature. Following a $1 \mathrm{~h}$ incubation in PBS containing 5\% BSA to block nonspecific immunoreactive sites, cells were treated overnight at $4{ }^{\circ} \mathrm{C}$ with rabbit polyclonal anti-UTR (Alomone Lab, Jerusalem, Israel) or normal rabbit IgG (GenScript, Piscataway, NJ, USA). After a wash, cells were incubated for $1 \mathrm{~h}$ at room temperature with Alexa 555-conjugated Donkey Anti-Rabbit (Life Technologies). Following wash and mount, fluorescence images were acquired using a Zeiss LSM Pascal laser-scanning confocal microscope.

\section{Western immunoblotting}

Afferent arterioles were homogenized in ice-cold RIPA buffer (Thermo Scientific, Rockford, IL, USA) followed by

Published by Bioscientifica Ltd. 
centrifugation to extract protein. Protein lysates were mixed with SDS sample buffer containing 5\% $\beta$-mercaptoethanol and boiled at $\sim 100{ }^{\circ} \mathrm{C}$ for $5 \mathrm{~min}$. Protein samples were thereafter resolved on a 7\% NuPAGE TrisAcetate Gel (Life Technologies) and then transferred to polyvinylidene difluoride membranes using a Pierce Fast Semi-Dry Blotter (Thermo Scientific). Nonspecific binding sites on the membranes were blocked by Tris buffered saline supplemented with $0.1 \%$ Tween 20 (TBS-T) and 5\% nonfat milk (Research Products International Corp., Mount Prospect, IL, USA) for $1 \mathrm{~h}$ at room temperature. The membranes were probed with rabbit polyclonal antiUTR (GPR14; Alpha Diagnostic International, Inc., San Antonio, TX, USA) overnight at $4{ }^{\circ} \mathrm{C}$. After washing with TBS-T, the membranes were incubated in a HRP-conjugated secondary antibody for $\sim 1 \mathrm{~h}$ at room temperature. Membranes were then processed with a Pierce Chemiluminescence kit (Thermo Scientific) and immunoreactive proteins were visualized on a Kodak Imaging system (Carestream Molecular Imaging, Rochester, NY, USA).

\section{Renal hemodynamic measurements}

Newborn pigs were anesthetized with ketamine hydrochloride $(20 \mathrm{mg} / \mathrm{kg})$ and xylazine $(2.2 \mathrm{mg} / \mathrm{kg})$ intramuscularly and maintained on $\alpha$-chloralose $(50 \mathrm{mg} / \mathrm{kg}$, i.v.) at $37^{\circ} \mathrm{C}$. The animals were intubated via tracheostomy and mechanically ventilated. Animals were continually monitored during experiments for anesthesia depth and re-dosed if necessary. The right femoral artery was catheterized for continuous measurement of mean arterial pressure (MAP) using a MLT1199 physiological pressure transducer (ADInstrument, Colorado Spring, CO, USA). Another catheter was inserted in the left femoral artery and advanced through the abdominal aorta until its tip was positioned at the junction of the aorta and left renal artery for intrarenal administration of drugs. The position of the catheter tip was confirmed at the end of each experiment. A femoral vein was also catheterized for anesthetic and fluid administration. Arterial blood partial pressures of $\mathrm{CO}_{2}$ and $\mathrm{O}_{2}, \mathrm{pH}$, and hematocrit were measured periodically with a Blood Gas Analyzer (Instrumentation Laboratory, Lexington, MA, USA). Ventilation was adjusted to maintain $\mathrm{PCO}_{2}, \mathrm{PO}_{2}$, and $\mathrm{pH}$ at physiological $\sim 30 \mathrm{mmHg},>85 \mathrm{mmHg}$, and 7.4 respectively.

The left kidneys of newborn pigs were exposed retroperitoneally through flank incisions to allow clear access to the renal pedicles. To determine total RBF, a left renal artery was carefully separated from the vein and connective tissues. A flow probe (Transonic Systems, Inc.,
Ithaca, NY, USA) was then placed around the main renal artery and connected to a T206 dual channel small animal flow meter (Transonic Systems). Regional RBF in the pigs was measured using laser Doppler flowmetry (LDF). A laser Doppler probe (PF 407) connected to a holder (Perimed, Jarfalla, Sweden) was placed on the kidney surface to measure cortical blood flow (CBF). Medullary blood flow (MBF) was measured using a needle probe (Perimed) inserted into the kidney to a depth of $\sim 8 \mathrm{~mm}$. The laser Doppler probes were connected to a flow meter (Periflux 4001, Perimed). After each experiment, the position of the intrarenal probe tip was confirmed by dissecting the kidneys. CBF and MBF measurements were obtained as laser Doppler perfusion unit (PU). Laser Doppler probes were calibrated with a standard calibration device using a motility standard (Perimed) such that 1 PU corresponds to an analog output of $10 \mathrm{mV}$. Data were acquired and analyzed using a PowerLab data acquisition system and LabChart software (ADInstrument).

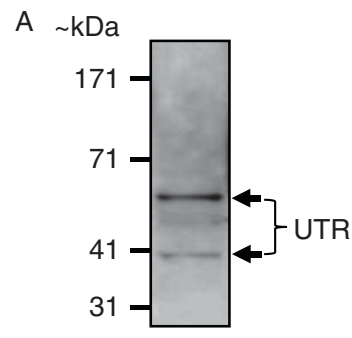

B

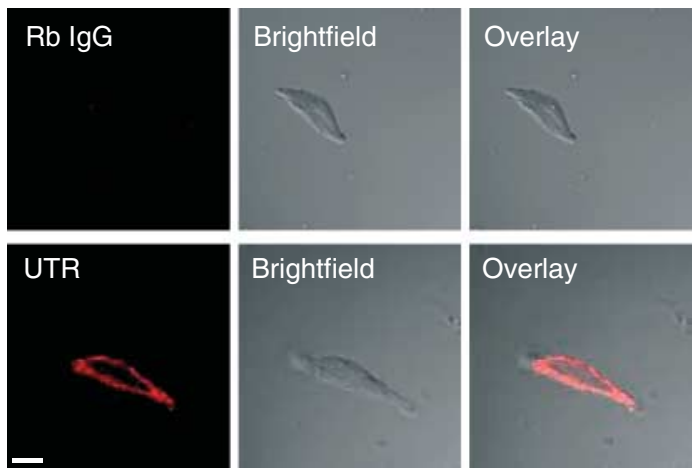

Figure 1

Newborn pig renal afferent arterioles and arteriolar smooth muscle cells express UTR protein. (A) Western immunoblotting detected unglycosylated ( $\sim 40 \mathrm{kDa})$ and glycosylated ( $\sim 60 \mathrm{kDa})$ forms of UTR in newborn pig renal afferent arterioles. (B) Immunofluorescence staining demonstrating plasma membrane localization of UTR in smooth muscle cells isolated from newborn pig renal afferent arterioles. Negative controls prepared using normal rabbit (Rb) IgG did not show fluorescence. Bar $=10 \mu \mathrm{m}$. 
Table 1 Basal values of MAP and renal hemodynamic parameters measured in newborn pigs

\begin{tabular}{l} 
\\
\hline $\operatorname{MAP}(\mathrm{mmHg})$ \\
$\operatorname{RBF}(\mathrm{ml} / \mathrm{min})$ \\
$\operatorname{RVR}(\mathrm{mmHg} / \mathrm{ml}$ per $\mathrm{min})$ \\
CBF (LDF PU) \\
MBF (LDF PU)
\end{tabular}

${ }^{*} P<0.05$, compared with MBF.

\section{Chemicals}

Unless otherwise stated, all reagents were purchased from Sigma Chemical. Human UII (hUII), urantide, U-73122, 2-APB, and ketamine/xylazine were purchased from California Peptide, Inc. (Napa, CA, USA), Peptide International (Louisville, KY, USA), Santa Cruz (Santa Cruz Biotechnology, Inc.), Cayman Chemicals (Ann Arbor, MI, USA), and Butler Schein Animal Health Supply (North Dublin, OH, USA) respectively.

\section{Statistical analysis}

All data are expressed as mean \pm s.e.m. Statistical significance was determined using Student's $t$-tests for paired or unpaired data and ANOVA with Student-Newman-Keuls for multiple comparisons tests. A $P$ value $<0.05$ was considered significant.

\section{Results}

\section{Newborn pig renal afferent arterioles and arteriolar smooth muscle cells express UTR protein}

Western blot analysis of neonatal afferent arterioles using a polyclonal rabbit anti-UTR antibody detected $\sim 40$ and $\sim 60 \mathrm{kDa}$ immunoreactive bands corresponding to the approximate molecular weights of unglycosylated and glycosylated UTR respectively (Fig. 1A). Immunofluorescence staining of smooth muscle cells isolated from neonatal pig afferent arterioles also revealed membrane localization of UTR in cells probed with rabbit anti-UTR antibody but not normal rabbit IgG (Fig. 1B). These data confirm that UTR protein is expressed in neonatal renal afferent arterioles and localized in the plasma membrane of afferent arteriolar smooth muscle cells.

\section{hUII elevates MAP and RVR but attenuates RBF in newborn pigs}

Basal MAP, RBF, and RVR in anesthetized newborn pigs are shown in Table 1. Cumulative intrarenal arterial bolus

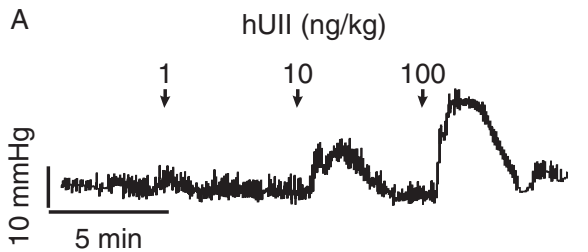

B
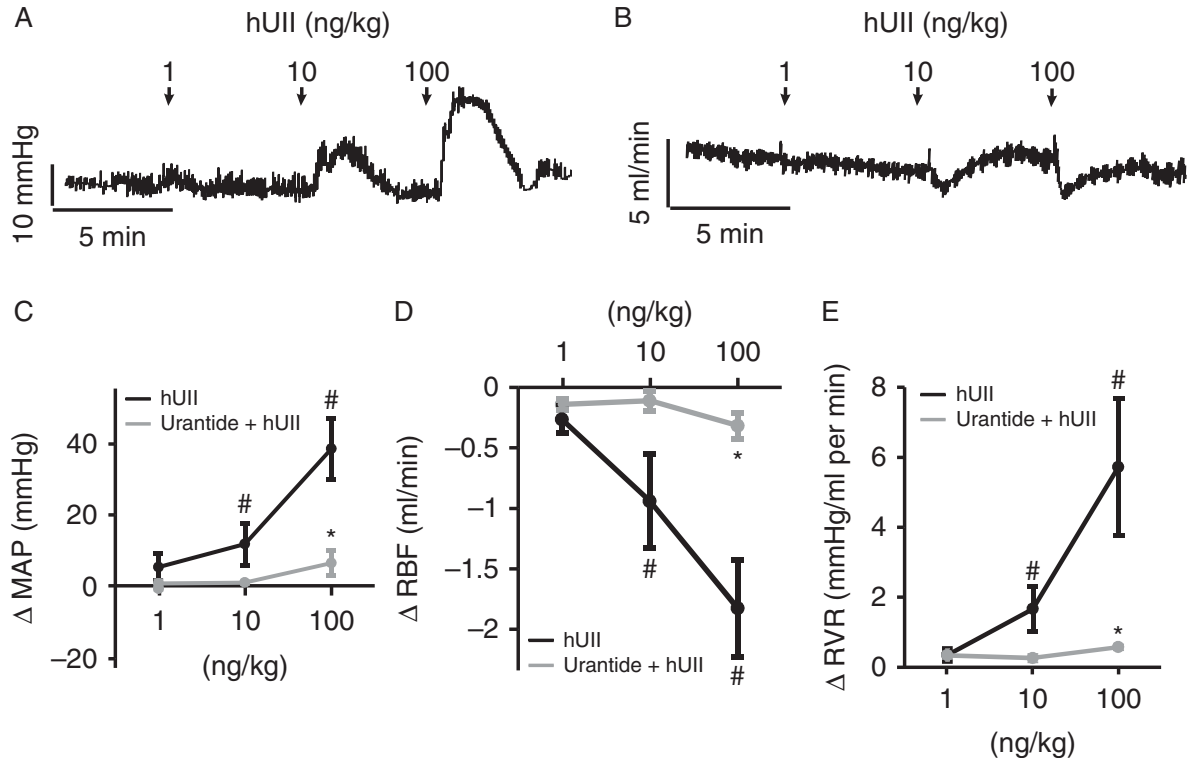

Figure 2

hUll elevates MAP and RVR but attenuates RBF in newborn pigs. ( $A$ and $B$ ) Exemplar tracings illustrating the effects of hUll on newborn pig MAP and RBF respectively. (C, D and E) Mean ( \pm s.E.M.) data showing that hUII dose dependently increased $\operatorname{MAP}(n=6)$, attenuated $\operatorname{RBF}(n=4)$, and elevated RVR $(n=4)$ in newborn pigs and that urantide $(20 \mu \mathrm{g} / \mathrm{kg})$ inhibited these effects. hUII and urantide were co-administered to the piglets $\sim 10 \mathrm{~min}$ after intrarenal arterial bolus injection of urantide. ${ }^{\#} P<0.05$ when compared with basal values; ${ }^{\star} P<0.05$ when compared with hUll-induced responses.

Published by Bioscientifica Ltd. 
injection of hUII dose dependently increased MAP in newborn pigs (Fig. 2A and C). To determine the effect of hUII on newborn pig RVR, we first measured RBF. As illustrated in Fig. 2B and D, hUII dose dependently reduced RBF in newborn pigs. RVR, calculated as a ratio of MAP:RBF was increased by hUII in the piglets (Fig. 2E). These findings indicate that intrarenal arterial administration of hUII elevates MAP and RVR and reduces RBF in newborn pigs.

\section{hUll reduces cortical but increases medullary perfusion in newborn pigs}

To examine whether there is a regional variation in hUII-induced renal hemodynamic changes in newborn pigs, we measured blood perfusion in cortical and medullary regions of newborn pig kidneys. Basal CBF was $\sim 55 \%$ more than MBF in newborn pigs (Table 1 ). hUII dose dependently decreased $\mathrm{CBF}$ in newborn pigs (Fig. 3A and C). In contrast, hUII elevated MBF in the pigs (Fig. 3B and D). These data indicate that hUII induces regionselective regulation of renal perfusion in newborn pigs.

\section{UTR mediates renal hemodynamic effects of hUII in newborn pigs}

To test the hypothesis that UTR mediates renal hemodynamic effects of hUII in newborn pigs, we studied the effect of urantide, a selective UTR antagonist on hUIIinduced renal hemodynamic changes in piglets. Urantide did not alter RBF, RVR, CBF, or MBF in newborn pigs (Table 2). However, urantide significantly reduced MAP by $\sim 4 \mathrm{mmHg}$ in the piglets (Table 2). Furthermore, urantide attenuated hUII-induced pressor effect and renal hemodynamic changes in newborn pigs (Figs 2 and 3). These findings suggest that inhibition of UTR reduces MAP in newborn pigs. Our data also indicate that UTR mediates hUII-induced pressor effect and renal hemodynamic changes in the piglets.

\section{Type 1 Angll receptors are not involved in hUll-induced pressor effect and renal hemodynamic changes in newborn pigs}

Next, we investigated whether AngII system contributes to renal hemodynamic responses of newborn pigs to hUII. Losartan, a selective type 1 AngII $\left(\mathrm{AT}_{1}\right)$ receptor antagonist, did not alter basal RBF, RVR, CBF, or MBF but significantly reduced MAP by $\sim 6 \mathrm{mmHg}$ in newborn pigs (Table 2). Losartan essentially abolished AngII-induced
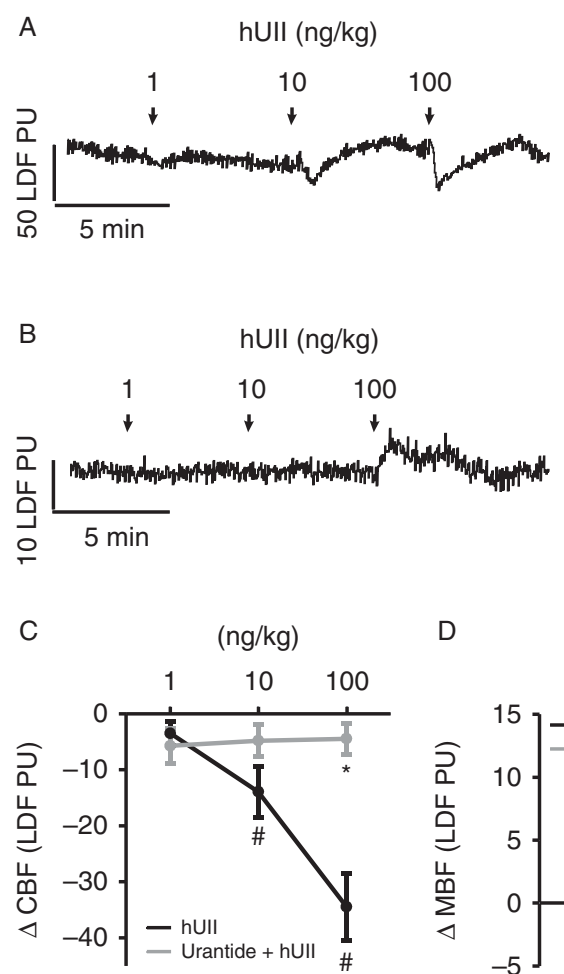

D

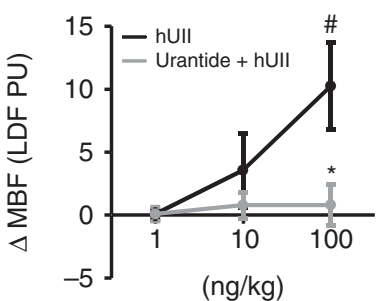

Figure 3

hUll reduces cortical but increases medullary perfusion in newborn pigs. (A and $B$ ) Representative tracings showing the effect of hUll on newborn pig $\mathrm{CBF}$ and MBF respectively. (C and D) Mean ( \pm s.E.M.) data illustrating that hUll dose dependently reduced CBF but increased MBF in newborn pigs and that urantide $(20 \mu \mathrm{g} / \mathrm{kg})$ attenuated these effects. hUll and urantide were co-administered to the piglets $\sim 10 \mathrm{~min}$ after intrarenal arterial bolus injection of urantide. $n=6$ each; ${ }^{\#} P<0.05$ when compared with basal values; $* P<0.05$ when compared with hUll-induced responses.

pressor effect and renal hemodynamic changes in newborn pigs (Table 3 ). In contrast, losartan did not alter pressor effect and renal hemodynamic responses to hUII in the piglets (Fig. 4A, B, C, D and E). Collectively, our data indicate that hUII-induced pressor effect and renal hemodynamic changes in newborn pigs are independent of $\mathrm{AT}_{1}$ receptors.

\section{Activation of the phospholipase C/inositol 1,4,5 trisphosphate pathway contributes to hUll-induced pressor effect and renal hemodynamic changes in newborn pigs}

To test the hypothesis that phospholipase C (PLC)/inositol 1,4,5 trisphosphate $\left(\mathrm{IP}_{3}\right)$-mediated renal vasoconstriction contributes to hUII-induced pressor effect and renal hemodynamic changes in newborn pigs, we studied the effect of U-73122, a PLC inhibitor and 2-APB, an $\mathrm{IP}_{3}$ receptor $\left(\mathrm{IP}_{3} \mathrm{R}\right)$ antagonist on hUII-induced MAP elevation

Published by Bioscientifica Ltd 
Table 2 MAP and renal hemodynamic responses to urantide $(20 \mu \mathrm{g} / \mathrm{kg})$, losartan $(1 \mathrm{mg} / \mathrm{kg}), \mathrm{U}-73122(10 \mu \mathrm{g} / \mathrm{kg})$, and $2-\mathrm{APB}$ $(2 \mathrm{mg} / \mathrm{kg})$ in newborn pigs. Data are expressed as mean \pm s.E.M.

\begin{tabular}{|c|c|}
\hline & $\triangle \mathbf{M A P}(\mathrm{mmHg})$ \\
\hline Urantide & $*-3.5 \pm 0.9(n=6)$ \\
\hline Losartan & $*-5.5 \pm 1.2(n=13)$ \\
\hline U-73122 & $-0.6 \pm 0.6(n=5)$ \\
\hline $2-A P B$ & $-1.4 \pm 1.4(n=6)$ \\
\hline
\end{tabular}

\begin{tabular}{c}
$\Delta \mathbf{R B F}(\mathrm{ml} / \mathrm{min})$ \\
\hline$-0.1 \pm 0.1(n=4)$ \\
$0.1 \pm 0.1(n=12)$ \\
$0.1 \pm 0.1(n=5)$ \\
$0.2 \pm 0.2(n=4)$
\end{tabular}

\begin{tabular}{c}
$\Delta \mathbf{R V R}(\mathrm{mmHg} / \mathrm{ml}$ per $\min )$ \\
\hline $0.2 \pm 0.2(n=4)$ \\
$-0.8 \pm 0.4(n=12)$ \\
$-0.3 \pm 0.2(n=5)$ \\
$-0.5 \pm 0.4(n=4)$
\end{tabular}

\begin{tabular}{c}
$\Delta$ CBF (LDF PU) \\
\hline$-5.3 \pm 5.0(n=6)$ \\
$6.0 \pm 3.5(n=13)$ \\
$-2.3 \pm 1.9(n=5)$ \\
$-7.4 \pm 4.0(n=6)$ \\
\hline \hline
\end{tabular}

\begin{tabular}{c}
\hline$\Delta$ MBF $($ LDF PU) \\
\hline $1.5 \pm 1.2(n=6)$ \\
$-1.9 \pm 1.5(n=13)$ \\
$2.9 \pm 1.9(n=5)$ \\
$1.6 \pm 1.1(n=5)$
\end{tabular}

$* P<0.05$, compared with basal values.

and renal hemodynamic changes in piglets. U-73122 did not alter basal MAP, RBF, RVR, CBF, and MBF in newborn pigs (Table 2). However, U-73122 inhibited hUII-induced elevation in MAP and RVR (Fig. 5A and B). U-73122 also attenuated hUII-induced decrease in RBF and CBF but not hUII-induced increase in MBF (Fig. 5C, D and E). These data suggest that PLC activation is involved in hUII-induced pressor effect and renal vasoconstriction in newborn pigs.

Similarly, 2-APB did not alter basal MAP, RBF, RVR, $\mathrm{CBF}$, and MBF in newborn pigs (Table 2). However, 2-APB attenuated hUII-induced MAP and RVR elevations, RBF and $\mathrm{CBF}$ reductions, but not MBF increase (Fig. 6A, B, C, D and $\mathrm{E}$ ). These findings signify that $\mathrm{IP}_{3} \mathrm{Rs}$ play a role in pressor and renal vascular effects of hUII in the piglets. Taken together, our data suggest that the PLC/IP 3 pathway contributes to hUII-induced pressor effect and alterations in RBF, RVR, and CBF but not MBF in newborn pigs.

\section{Discussion}

We present new findings in this study indicating that UIIinduced activation of renal vascular UTR regulates blood pressure and regional RBF in neonatal pigs. hUII elevates MAP and RVR and attenuates total RBF in newborn pigs. hUII also reduces CBF but elevates MBF in the piglets. Furthermore, our data indicate that hUII-induced MAP elevation and renal hemodynamic changes in newborn pigs are independent of $\mathrm{AT}_{1}$ receptors but involve the $\mathrm{PLC} / \mathrm{IP}_{3}$ signaling pathway.
UII activity is mediated by UTR, a G protein-coupled receptor (GPCR; Ames et al. 1999, Liu et al. 1999). Both unglycosylated $(\sim 42 \mathrm{kDa})$ and glycosylated $(\sim 60 \mathrm{kDa})$ forms of UTR protein have been identified in human adrenocortical tissues and COS-7 cells overexpressing UTR (Boucard et al. 2003, Giuliani et al. 2009). Ventricular samples from rats express the unglycosylated form of UTR, whereas the glycosylated form was the only immunoreactive UTR protein identified in rat kidneys, coronary arteries, and cultured coronary artery smooth muscle cells (Gong et al. 2004, Abdel-Razik et al. 2008b, DominguezRodriguez et al. 2012). In this study, we found that newborn pig renal afferent arterioles express both unglycosylated and glycosylated forms of UTR. Thus, the expression pattern of UTR protein isoforms may vary between species and tissues. Our findings also confirm that similar to previous reports in adult rats (Ashton 2006, Song et al. 2006), UTR are expressed in neonatal pig renal vessels.

Previous studies examining renal actions of UII in mature animals have yielded inconsistent findings. For example, intrarenal arterial infusion of hUII did not alter MAP but increased RBF, GFR, $\mathrm{UV}$, and $\mathrm{U}_{\mathrm{Na}} \mathrm{V}$ in rats (Zhang et al. 2003). In contrast, i.v. injection of rUII reduced blood pressure, $\mathrm{RBF}, \mathrm{GFR}, \mathrm{UV}, \mathrm{U}_{\mathrm{Na}} \mathrm{V}$, and $\mathrm{U}_{\mathrm{K}} \mathrm{V}$ in rats (Song et al. 2006). I.v. injections of hUII also decreased blood pressure, RVR, and GFR but did not alter RBF and UNaV in rats (Ovcharenko et al. 2006). These conflicting reports have been attributed to several factors, including route of administration, dosage, and source of UII (Ashton 2006,

Table 3 MAP and renal hemodynamic responses of newborn pigs to Angll in the absence and presence of losartan (1 mg/kg). Data are expressed as mean \pm S.E.M. Angll and losartan were co-administered to the piglets $\sim 10$ min after intrarenal arterial bolus injection of losartan

\begin{tabular}{|c|c|c|}
\hline & DMAP $(\mathrm{mmHg})$ & $\Delta \mathbf{R B F}(\mathrm{ml} / \mathrm{min})$ \\
\hline Angll & $22.4 \pm 3.0$ & $-5.0 \pm 0.8$ \\
\hline Losartan + Angll & $* 1.6 \pm 0.8$ & $*-0.2 \pm 0.2$ \\
\hline
\end{tabular}

\begin{tabular}{c}
$\Delta \mathbf{R V R}(\mathrm{mmHg} / \mathrm{ml}$ per $\mathrm{min})$ \\
\hline $\begin{array}{c}18.8 \pm 4.8 \\
0.3 \pm 0.2\end{array}$
\end{tabular}

\begin{tabular}{c}
$\Delta$ CBF $($ LDF PU) \\
\hline$-90.4 \pm 17.4$ \\
$*-1.2 \pm 3.5$ \\
\hline
\end{tabular}

\begin{tabular}{r}
$\Delta$ MBF (LDF PU) \\
\hline$-15.5 \pm 7.2$ \\
$\star 2.3 \pm 1.1$
\end{tabular}

$\star P<0.05$, compared with Angll; $n=7$, each. 


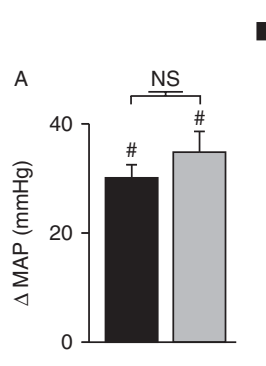

hUII $\square$ Losartan + hUII

B
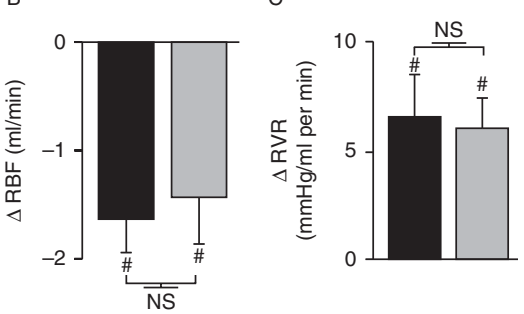

D
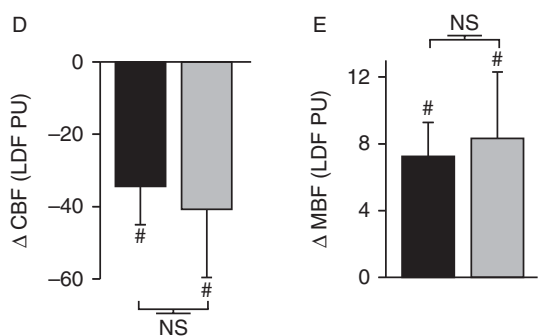

Figure 4

hUll-induced pressor effect and renal hemodynamic changes in newborn pigs are independent of $A T_{1}$ receptors. ( $A, B, C, D$ and E) Mean ( \pm s.E.M.) data illustrating that losartan $(1 \mathrm{mg} / \mathrm{kg})$ did not alter hUll $(100 \mathrm{ng} / \mathrm{kg})$ induced MAP elevation and renal hemodynamic changes in newborn pigs. hUII and losartan were co-administered to the piglets $\sim 10 \mathrm{~min}$ after intrarenal arterial bolus injection of losartan. $n=7$ each; ${ }^{\#} P<0.05$ when compared with basal values; NS, not significant.

Zoccali \& Mallamaci 2008, Ross et al. 2010, Tsoukas et al. 2011). However, the cyclic hexapeptide sequence in UII carboxyl-terminus, which is responsible for its biological activity, is highly conserved between species (Itoh et al. 1987, Conlon et al. 1990, Coulouarn et al. 1998, Douglas et al. 2004). Hence, it is unlikely that the physiological function of UII is dependent on its source (Douglas et al. 2000).

Data presented here indicate that intrarenal arterial administration of hUII elevates RVR and MAP in newborn pigs. However, a previous study showed that intrarenal arterial infusion of hUII did not alter MAP in adult rats (Zhang et al. 2003). These conflicting findings could be due to species differences and/or animal age. Urantide induced a small but significant decrease in MAP in newborn pigs, suggesting that endogenous UII regulates blood pressure in the piglets. However, urantide did not alter basal RBF, RVR, and regional renal perfusion in the piglets. These results raise the possibility that the hypotensive effect of urantide may be due to its systemic but not localized renal vasoregulatory actions. Neurons of the brain and spinal cord express UII (Coulouarn et al. 1998, Douglas et al. 2004, Ross et al. 2010). Studies have also shown that UII can modulate cardiovascular homeostasis via central neural mechanisms (Gibson et al. 1986,

Lu et al. 2002, Lin et al. 2003). However, the expression and function of UII system in renal plexus have not been characterized. Hence, future studies are needed to explore whether hUII alters neonatal blood pressure and renal hemodynamics via regulation of renal sympathetic nerve activity.

Renal perfusion exhibits considerable regional heterogeneity. Changes in renal CBF are not always replicated in the medullary or papillary regions because medullary hemodynamics can be regulated independently of renal CBF (Pallone et al. 1990, Navar et al. 1996, Mattson 2003). Vasoactive agents, including AngII, dopamine, arginine vasopressin, atrial natriuretic peptide, and bradykinin have been demonstrated to induce renal region-specific hemodynamic changes (Takezawa et al. 1987, Pallone et al. 1990, Nobes et al. 1991, Mattson \& Cowley 1993, Heyman et al. 1995, Badzynska et al. 2002, Igbe et al. 2012). However, the effect of UII on regional RBF was unclear. In this study, we show that hUII-induced activation of UTR dose dependently reduced CBF but elevated MBF in newborn pigs, suggesting that hUII differentially regulates neonatal regional renal perfusion. Although hUII-induced elevation in MBF in the pigs occurred at the highest dose tested, it is likely that the medullary actions of UII result in localized vasodilation. Endogenous mediators of renal vasodilation, including nitric oxide (NO) and vasodilatory PGs, exert larger vasoregulatory

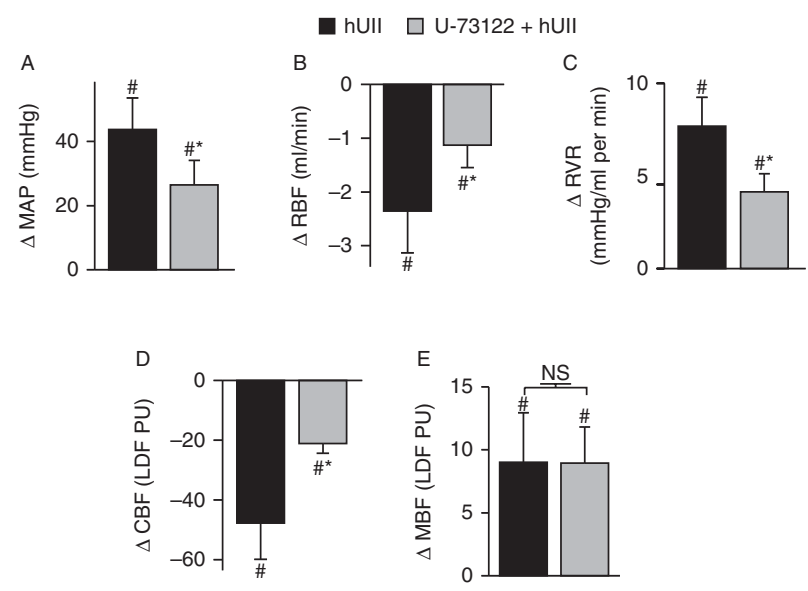

Figure 5

PLC activation mediates hUll-induced pressor effect and renal hemodynamic changes in newborn pigs. (A, B, C and D) Mean ( \pm s.E.M.) data signifying that hUII (100 ng/kg)-induced changes in MAP, RBF, RVR, and CBF were inhibited by $\mathrm{U}-73122(10 \mu \mathrm{g} / \mathrm{kg})$ in newborn pigs. (E) Mean ( \pm S.E.M.) data illustrating that U-73122 did not alter hUll-induced MBF elevation in newborn pigs. hUll and U-73122 were co-administered to the piglets $\sim 10$ min after intrarenal arterial bolus injection of U-73122. $n=5$ each; ${ }^{\#} P<0.05$ when compared with basal values; ${ }^{*} P<0.05$ when compared with hUll-induced responses; NS, not significant.

Published by Bioscientifica Ltd. 

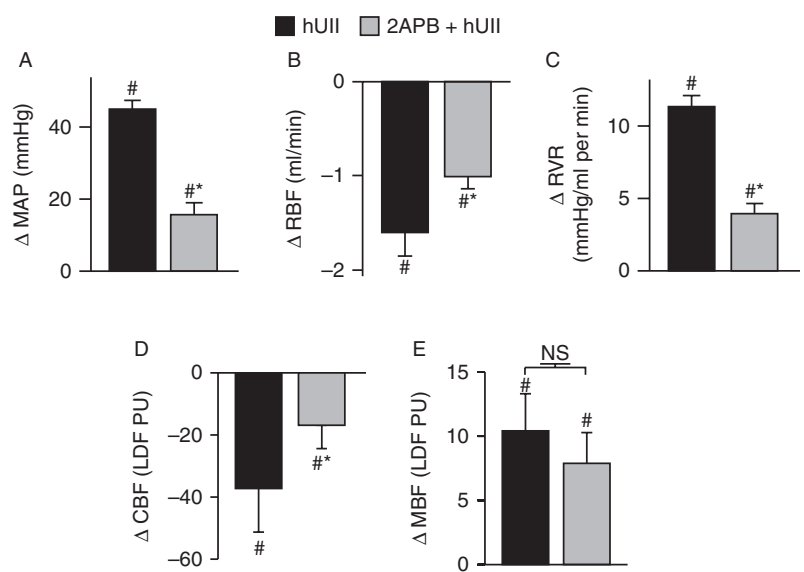

\section{Figure 6}

$I_{3} R$ activation contributes to hUll-induced pressor effect and renal hemodynamic changes in newborn pigs. (A, B, C and D) Mean ( \pm s.E.M.) data showing that hUll $(100 \mathrm{ng} / \mathrm{kg})$-induced changes in $\operatorname{MAP}(n=6), \operatorname{RBF}(n=4)$, $\operatorname{RVR}(n=4)$, and CBF $(n=6)$ were attenuated by 2 -APB $(2 \mathrm{mg} / \mathrm{kg})$ in newborn pigs. (E) Mean ( \pm S.E.M.) data demonstrating that hUll-induced $\operatorname{MBF}(n=5)$ was unaltered by 2-APB in newborn pigs. hUll and 2-APB were co-administered to the piglets $\sim 10 \mathrm{~min}$ after intrarenal arterial bolus injection of 2-APB. ${ }^{\# P}<0.05$ when compared with basal values; ${ }^{*} P<0.05$ when compared with hUll-induced responses; NS, not significant.

effects in renal medulla than the cortex (Navar et al. 1996). UII stimulates $\mathrm{NO}$, prostacyclin, and $\mathrm{PGE}_{2}$ release in rat coronary arteries (Ishihata et al. 2005). UII also elevated NO production in rat renal artery endothelium (Zhang et al. 2003). Moreover, the physiological activity of NO and vasodilatory PGs are elevated in fetal and newborn kidneys compared with adults (Hook \& Bailie 1979, Toth-Heyn et al. 2000). Conceivably, hUII elevates MBF in newborn pigs via localized generation of $\mathrm{NO}$ and/or vasodilatory PGs in the medulla. However, these possibilities require further investigations.

Studies have suggested that a functional cross talk exists between UII and AngII systems. UII-induced elevation in myocardial distensibility and negative ionotropic and lusitropic effects in rabbits were inhibited by losartan (Fontes-Sousa et al. 2009). Furthermore, AngIIinduced vasoconstriction was elevated in hUII-pretreated rat aortic segments (Wang et al. 2007). Data here show that at the dose that essentially abolished AngII-induced hypertension and renal hemodynamic changes, losartan did not alter pressor and renal hemodynamic responses of newborn pigs to hUII, indicating that renal actions of UII in newborn pigs are independent of $\mathrm{AT}_{1}$ receptors.

In vascular smooth muscle cells, activation of PLC-coupled GPCRs by a wide variety of vasoconstrictors stimulates phosphoinositide hydrolysis, resulting in generation of $\mathrm{IP}_{3}$ (Berridge 1993). $\mathrm{IP}_{3}$ binds to sarcoplasmic reticulum (SR)-localized $\mathrm{IP}_{3}$ Rs leading to $\mathrm{Ca}^{2+}$ release from $\mathrm{SR} \mathrm{Ca}^{2+}$ store, an elevation in intracellular $\mathrm{Ca}^{2+}$, and vasoconstriction (Berridge 1993, Sanders 2001). In cerebral and mesenteric arteries, $\mathrm{IP}_{3}$ mediated vasoconstriction can also occur independently of $\mathrm{SR} \mathrm{Ca}^{2+}$ release and due to a molecular and functional coupling between smooth muscle cell type $1 \mathrm{IP}_{3} \mathrm{R}\left(\mathrm{IP}_{3} \mathrm{R} 1\right)$ and canonical transient receptor potential 3 (TRPC3) channels (Xi et al. 2008, Adebiyi et al. 2010, 2012). However, it is unclear whether a coupling exists between $\mathrm{IP}_{3} \mathrm{R} 1$ and TRPC 3 channels in renal vascular smooth muscle cells. hUII constricts rabbit aortic smooth muscle by stimulating PLC-dependent elevation in inositol phosphates, suggesting that $\mathrm{PLC} / \mathrm{IP}_{3}$-mediated intracellular $\mathrm{Ca}^{2+}$ elevation contributes to hUII-induced vasoconstriction (Saetrum et al. 2000). Here, U-73122, a PLC inhibitor, and 2-APB, an $\mathrm{IP}_{3} \mathrm{R}$ antagonist, attenuated hUII-induced MAP and RVR elevations, RBF and CBF reductions, but not $\mathrm{MBF}$ increase. These data suggest that $\mathrm{PLC} / \mathrm{IP}_{3}$-mediated renal vasoconstriction is involved in hUII-induced neonatal renal hemodynamic changes. Of note, 2-APB can also block store-operated $\mathrm{Ca}^{2+}$ (SOC) channels (Dobrydneva \& Blackmore 2001, Bootman et al. 2002). Given that UII also induces vasoconstriction by activating store-operated $\mathrm{Ca}^{2+}$ entry (Dominguez-Rodriguez et al. 2012), SOC channel blockade may contribute to the inhibitory effect of 2-APB on hUII-induced neonatal renal hemodynamic changes.

In summary, data from our study indicate that UII regulates renal hemodynamics in neonatal pigs. Intrarenal arterial bolus administration of hUII elevates RVR and MAP but decreases total RBF in newborn pigs. In addition, hUII reduces CBF but increases MBF in the piglets. We also propose that hUII-induced activation of renal vascular UTR stimulates PLC/IP ${ }_{3}$-mediated vasoconstriction, leading to an increase in RVR and MAP and a decrease in RBF and $\mathrm{CBF}$ in newborn pigs.

\section{Declaration of interest}

The authors declare that there is no conflict of interest that could be perceived as prejudicing the impartiality of the research reported.

\section{Funding}

This work was supported by a start-up fund from UTHSC to A Adebiyi.

\section{Acknowledgements}

The authors thank Alex Fedinec for technical advice with animal ventilation and Dr Charles Leffler for critical reading of the manuscript.

Published by Bioscientifica Ltd. 


\section{References}

Abdel-Razik AE, Balment RJ \& Ashton N 2008a Enhanced renal sensitivity of the spontaneously hypertensive rat to urotensin II. American Journal of Physiology. Renal Physiology 295 F1239-F1247. (doi:10.1152/ ajprenal.90374.2008)

Abdel-Razik AE, Forty EJ, Balment RJ \& Ashton N $2008 b$ Renal haemodynamic and tubular actions of urotensin II in the rat. Journal of Endocrinology 198 617-624. (doi:10.1677/JOE-08-0260)

Adebiyi A, Zhao G, Narayanan D, Thomas-Gatewood CM, Bannister JP \& Jaggar JH 2010 Isoform-selective physical coupling of TRPC3 channels to $\mathrm{IP}_{3}$ receptors in smooth muscle cells regulates arterial contractility. Circulation Research 106 1603-1612. (doi:10.1161/CIRCRESAHA. 110.216804)

Adebiyi A, Thomas-Gatewood CM, Leo MD, Kidd MW, Neeb ZP \& Jaggar JH 2012 An elevation in physical coupling of type 1 inositol 1,4,5trisphosphate $\left(\mathrm{IP}_{3}\right)$ receptors to transient receptor potential 3 (TRPC3) channels constricts mesenteric arteries in genetic hypertension. Hypertension 60 1213-1219. (doi:10.1161/HYPERTENSIONAHA. 112.198820)

Ames RS, Sarau HM, Chambers JK, Willette RN, Aiyar NV, Romanic AM, Louden CS, Foley JJ, Sauermelch CF, Coatney RW et al. 1999 Human urotensin-II is a potent vasoconstrictor and agonist for the orphan receptor GPR14. Nature 401 282-286. (doi:10.1038/45809)

Ashton N 2006 Renal and vascular actions of urotensin II. Kidney International 70 624-629. (doi:10.1038/sj.ki.5001621)

Badzynska B, Grzelec-Mojzesowicz M, Dobrowolski L \& Sadowski J 2002 Differential effect of angiotensin II on blood circulation in the renal medulla and cortex of anaesthetised rats. Journal of Physiology $\mathbf{5 3 8}$ 159-166. (doi:10.1113/jphysiol.2001.012921)

Balat A, Karakok M, Yilmaz K \& Kibar Y 2007 Urotensin-II immunoreactivity in children with chronic glomerulonephritis. Renal Failure 29 573-578. (doi:10.1080/08860220701392108)

Berridge MJ 1993 Inositol trisphosphate and calcium signalling. Nature 361 315-325. (doi:10.1038/361315a0)

Bootman MD, Collins TJ, MacKenzie L, Roderick HL, Berridge MJ \& Peppiatt CM 2002 2-Aminoethoxydiphenyl borate (2-APB) is a reliable blocker of store-operated $\mathrm{Ca}^{2+}$ entry but an inconsistent inhibitor of InsP $_{3}$-induced $\mathrm{Ca}^{2+}$ release. FASEB Journal 16 1145-1150. (doi:10.1096/ fj.02-0037rev)

Bottrill FE, Douglas SA, Hiley CR \& White R 2000 Human urotensin-II is an endothelium-dependent vasodilator in rat small arteries. British Journal of Pharmacology 130 1865-1870. (doi:10.1038/sj.bjp.0703513)

Boucard AA, Sauve SS, Guillemette G, Escher E \& Leduc R 2003 Photolabelling the rat urotensin II/GPR14 receptor identifies a ligandbinding site in the fourth transmembrane domain. Biochemical Journal 370 829-838. (doi:10.1042/BJ20021566)

Conlon JM, Arnold-Reed D \& Balment RJ 1990 Post-translational processing of prepro-urotensin II. FEBS Letters 266 37-40. (doi:10.1016/ 0014-5793(90)81500-N)

Coulouarn Y, Lihrmann I, Jegou S, Anouar Y, Tostivint H, Beauvillain JC, Conlon JM, Bern HA \& Vaudry H 1998 Cloning of the cDNA encoding the urotensin II precursor in frog and human reveals intense expression of the urotensin II gene in motoneurons of the spinal cord. PNAS 95 15803-15808. (doi:10.1073/pnas.95.26.15803)

Dobrydneva Y \& Blackmore P 2001 2-Aminoethoxydiphenyl borate directly inhibits store-operated calcium entry channels in human platelets. Molecular Pharmacology 60 541-552.

Dominguez-Rodriguez A, Diaz I, Rodriguez-Moyano M, CalderonSanchez E, Rosado JA, Ordonez A \& Smani T 2012 Urotensin-II signaling mechanism in rat coronary artery: role of STIM1 and Orai1-dependent store operated calcium influx in vasoconstriction. Arteriosclerosis, Thrombosis, and Vascular Biology 32 1325-1332. (doi:10.1161/ATVBAHA.111.243014)
Douglas SA, Sulpizio AC, Piercy V, Sarau HM, Ames RS, Aiyar NV, Ohlstein EH \& Willette RN 2000 Differential vasoconstrictor activity of human urotensin-II in vascular tissue isolated from the rat, mouse, dog, pig, marmoset and cynomolgus monkey. British Journal of Pharmacology 131 1262-1274. (doi:10.1038/sj.bjp.0703690)

Douglas SA, Dhanak D \& Johns DG 2004 From 'gills to pills': urotensin-II as a regulator of mammalian cardiorenal function. Trends in Pharmacological Sciences 25 76-85. (doi:10.1016/j.tips.2003.12.005)

Fontes-Sousa AP, Pires AL, Monteiro-Cardoso VF \& Leite-Moreira AF 2009 Urotensin II-induced increase in myocardial distensibility is modulated by angiotensin II and endothelin-1. Physiological Research 58 653-660.

Forty EJ \& Ashton N 2012 Ontogeny of the renal urotensin II system in the rat. Experimental Physiology 97 785-795.

Gibson A, Wallace P \& Bern HA 1986 Cardiovascular effects of urotensin II in anesthetized and pithed rats. General and Comparative Endocrinology 64 435-439. (doi:10.1016/0016-6480(86)90080-8)

Giuliani L, Lenzini L, Antonello M, Aldighieri E, Belloni AS, Fassina A, Gomez-Sanchez C \& Rossi GP 2009 Expression and functional role of urotensin-II and its receptor in the adrenal cortex and medulla: novel insights for the pathophysiology of primary aldosteronism. Journal of Clinical Endocrinology and Metabolism 94 684-690. (doi:10.1210/ jc.2008-1131)

Gong H, Wang YX, Zhu YZ, Wang WW, Wang MJ, Yao T \& Zhu YC 2004 Cellular distribution of GPR14 and the positive inotropic role of urotensin II in the myocardium in adult rat. Journal of Applied Physiology 97 2228-2235. (doi:10.1152/japplphysiol.00540.2004)

Heyman SN, Kaminski N \& Brezis M 1995 Dopamine increases renal medullary blood flow without improving regional hypoxia. Experimental Nephrology 3 331-337.

Hook JB \& Bailie MD 1979 Perinatal renal pharmacology. Annual Review of Pharmacology and Toxicology 19 491-509. (doi:10.1146/annurev.pa.19. 040179.002423)

Igbe I, Omogbai EK \& Oyekan AO 2012 Differential effects of angiotensin II on intra-renal hemodynamics in rats; contribution of prostanoids, NO and $\mathrm{K}^{+}$channels. Pharmacology \& Pharmacy 3 388-396. (doi:10.4236/ pp.2012.34052)

Ishihata A, Ogaki T, Aita T \& Katano Y 2005 Role of prostaglandins in urotensin II-induced vasodilatation in the coronary arteries of aged rats. European Journal of Pharmacology 523 119-126. (doi:10.1016/ j.ejphar.2005.09.018)

Itoh H, Itoh Y, Rivier J \& Lederis K 1987 Contraction of major artery segments of rat by fish neuropeptide urotensin II. American Journal of Physiology 252 R361-R366.

Langham RG, Kelly DJ, Gow RM, Zhang Y, Dowling JK, Thomson NM \& Gilbert RE 2004 Increased expression of urotensin II and urotensin II receptor in human diabetic nephropathy. American Journal of Kidney Diseases 44 826-831.

Lin Y, Tsuchihashi T, Matsumura K, Abe I \& Iida M 2003 Central cardiovascular action of urotensin II in conscious rats. Journal of Hypertension 21 159-165. (doi:10.1097/00004872-200301000-00026)

Liu Q, Pong SS, Zeng Z, Zhang Q, Howard AD, Williams DL Jr, Davidoff M, Wang R, Austin CP, McDonald TP et al. 1999 Identification of urotensin II as the endogenous ligand for the orphan G-protein-coupled receptor GPR14. Biochemical and Biophysical Research Communications 266 174-178. (doi:10.1006/bbrc.1999.1796)

Lu Y, Zou CJ, Huang DW \& Tang CS 2002 Cardiovascular effects of urotensin II in different brain areas. Peptides 23 1631-1635. (doi:10.1016/S0196-9781(02)00104-3)

MacLean MR, Alexander D, Stirrat A, Gallagher M, Douglas SA, Ohlstein EH, Morecroft I \& Polland K 2000 Contractile responses to human urotensinII in rat and human pulmonary arteries: effect of endothelial factors and chronic hypoxia in the rat. British Journal of Pharmacology 130 201-204. (doi:10.1038/sj.bjp.0703314)

Maguire JJ, Kuc RE \& Davenport AP 2000 Orphan-receptor ligand human urotensin II: receptor localization in human tissues and comparison of 
vasoconstrictor responses with endothelin-1. British Journal of Pharmacology 131 441-446. (doi:10.1038/sj.bjp.0703601)

Matsushita M, Shichiri M, Imai T, Iwashina M, Tanaka H, Takasu N \& Hirata Y 2001 Co-expression of urotensin II and its receptor (GPR14) in human cardiovascular and renal tissues. Journal of Hypertension 19 2185-2190. (doi:10.1097/00004872-200112000-00011)

Mattson DL 2003 Importance of the renal medullary circulation in the control of sodium excretion and blood pressure. American Journal of Physiology. Regulatory, Integrative and Comparative Physiology 284 R13-R27.

Mattson DL \& Cowley AW Jr 1993 Kinin actions on renal papillary blood flow and sodium excretion. Hypertension 21 961-965. (doi:10.1161/ 01.HYP.21.6.961)

Navar LG, Inscho EW, Majid SA, Imig JD, Harrison-Bernard LM \& Mitchell KD 1996 Paracrine regulation of the renal microcirculation. Physiological Reviews 76 425-536.

Nobes MS, Harris PJ, Yamada H \& Mendelsohn FA 1991 Effects of angiotensin on renal cortical and papillary blood flows measured by laser-Doppler flowmetry. American Journal of Physiology 261 F998-F1006.

Ovcharenko E, Abassi Z, Rubinstein I, Kaballa A, Hoffman A \& Winaver J 2006 Renal effects of human urotensin-II in rats with experimental congestive heart failure. Nephrology, Dialysis, Transplantation 21 1205-1211. (doi:10.1093/ndt/gfk049)

Pallone TL, Robertson CR \& Jamison RL 1990 Renal medullary microcirculation. Physiological Reviews 70 885-920.

Ponnuchamy B \& Khalil RA 2009 Cellular mediators of renal vascular dysfunction in hypertension. American Journal of Physiology. Regulatory, Integrative and Comparative Physiology 296 R1001-R1018. (doi:10.1152/ ajpregu.90960.2008)

Ross B, McKendy K \& Giaid A 2010 Role of urotensin II in health and disease. American Journal of Physiology. Regulatory, Integrative and Comparative Physiology 298 R1156-R1172. (doi:10.1152/ajpregu.00706.2009)

Saetrum OO, Nothacker H, Ehlert FJ \& Krause DN 2000 Human urotensin II mediates vasoconstriction via an increase in inositol phosphates. European Journal of Pharmacology 406 265-271. (doi:10.1016/ S0014-2999(00)00672-5)

Sanders KM 2001 Invited review: mechanisms of calcium handling in smooth muscles. Journal of Applied Physiology 91 1438-1449.

Shi Y, Cao YX, Lu N, Yao T \& Zhu YC 2008 Hemodynamic-independent anti-natriuretic effect of urotensin II in spontaneously hypertensive rats. Peptides 29 783-794. (doi:10.1016/i.peptides.2008.02.015)
Simpson CM, Smolich JJ, Shekerdemian LS \& Penny DJ 2010 Urotensin-II contributes to pulmonary vasoconstriction in a perinatal model of persistent pulmonary hypertension of the newborn secondary to meconium aspiration syndrome. Pediatric Research 67 150-157. (doi:10.1203/PDR.0b013e3181c345ea)

Song W, Abdel-Razik AE, Lu W, Ao Z, Johns DG, Douglas SA, Balment RJ \& Ashton N 2006 Urotensin II and renal function in the rat. Kidney International 69 1360-1368.

Stirrat A, Gallagher M, Douglas SA, Ohlstein EH, Berry C, Kirk A, Richardson M \& MacLean MR 2001 Potent vasodilator responses to human urotensin-II in human pulmonary and abdominal resistance arteries. American Journal of Physiology. Heart and Circulatory Physiology 280 H925-H928.

Takezawa K, Cowley AW Jr, Skelton M \& Roman RJ 1987 Atriopeptin III alters renal medullary hemodynamics and the pressure-diuresis response in rats. American Journal of Physiology 252 F992-F1002.

Toth-Heyn P, Drukker A \& Guignard JP 2000 The stressed neonatal kidney: from pathophysiology to clinical management of neonatal vasomotor nephropathy. Pediatric Nephrology 14 227-239. (doi:10.1007/ s004670050048)

Tsoukas P, Kane E \& Giaid A 2011 Potential clinical implications of the urotensin II receptor antagonists. Frontiers in Pharmacology 238. (doi:10.3389/fphar.2011.00038)

Wang YX, Ding YJ, Zhu YZ, Shi Y, Yao T \& Zhu YC 2007 Role of PKC in the novel synergistic action of urotensin II and angiotensin II and in urotensin II-induced vasoconstriction. American Journal of Physiology. Heart and Circulatory Physiology 292 H348-H359. (doi:10.1152/ajpheart. 00512.2006)

Xi Q, Adebiyi A, Zhao G, Chapman KE, Waters CM, Hassid A \& Jaggar JH $2008 \mathrm{IP}_{3}$ constricts cerebral arteries via $\mathrm{IP}_{3}$ receptor-mediated TRPC3 channel activation and independently of sarcoplasmic reticulum $\mathrm{Ca}^{2+}$ release. Circulation Research 102 1118-1126. (doi:10.1161/CIRCRESAHA.108.173948)

Zhang AY, Chen YF, Zhang DX, Yi FX, Qi J, Andrade-Gordon P, de Garavilla L, Li PL \& Zou AP 2003 Urotensin II is a nitric oxidedependent vasodilator and natriuretic peptide in the rat kidney. American Journal of Physiology. Renal Physiology 285 F792-F798.

Zoccali C \& Mallamaci F 2008 Urotensin II: a cardiovascular and renal update. Current Opinion in Nephrology and Hypertension 17 199-204. (doi:10.1097/MNH.0b013e3282f49566)

Received in final form 1 April 2013

Accepted 3 April 2013

Accepted Preprint published online 3 April 2013
(C) 2013 Society for Endocrinology Printed in Great Britain
Published by Bioscientifica Ltd. 